\title{
Identificación de calidad del servicio de gas domiciliario en Atlántico, Valle del Cauca y Bogotá, partiendo de peticiones, quejas y reclamos*
}

\section{Identification of residential gas quality of service in Atlántico, Valle del Cauca and Bogota based on petitions, complaints, and claims}

\section{Identificação da qualidade do serviço doméstico de gás no Atlântico, Valle del Cauca e Bogotá com base nas solicitações e reclamações}

\author{
Luisa Patricia Juvinao-Carbono \\ MS in Strategic Marketing Management, Institución Universitaria Politécnico Grancolombiano, Bogotá - Colombia \\ SENA Instructor, Carrera 55 N 152 - 40 Apt 103 Int 1 \\ ljuvi@hotmail.com \\ Sandra Patricia Rojas-Berrío \\ $\mathrm{PhD}$ in Administrative Sciences, Assistant Professor - Universidad Nacional de Colombia, Bogotá - Colombia \\ sprojas@unal.edu.co
}

\section{Óscar Javier Robayo-Pinzón}

MSc in Consumer Psychology, Assistant Professor - Institución Universitaria Politécnico Grancolombiano, Bogotá - Colombia osrobayo@poligran.edu.co

\begin{abstract}
This research identifies the quality levels of residential gas service based on petitions, complaints, and claims in the departments of Atlántico, Valle del Cauca, and in the city of Bogotá from 2006 to the first quarter of 2015. The information for this period was taken from the database of the Utilities Unique Information System (SUI for its name in Spanish) of the Superintendency of Residential Utilities. The analysis of the quantitative information gathered in order to measure the quality of the residential service indicates that the service has presented frequent interruptions since 2009, when the complaints

* Cómo citar: Juvinao-Carbono, L. P., Rojas-Berrío, S.P., Robayo-Pinzón, O. J. (2016). Identificación de calidad del servicio de gas domiciliario en Atlántico, Valle del Cauca y Bogotá, partiendo de peticiones, quejas y reclamos. Revista Libre Empresa, 13(2), 11-26 http://dx.doi. org/10.18041/libemp.2016.v13n2.26201
\end{abstract}


regarding quality, connections, and procedures increased considerably (getting the highest point in 2014.) On the other hand, the levels of dissatisfaction are higher in Valle del Cauca and Atlántico than in Bogotá. The results of the study indicate that companies should adjust the service provided and improve their response time when dealing with petitions, complaints, and claims from the users.

\section{Keywords}

Marketing; quality; services.

\section{Resumen}

Esta investigación identifica los niveles de calidad del servicio de gas domiciliario a partir de las peticiones, quejas y reclamos en los departamentos del Atlántico, Valle del Cauca y la ciudad de Bogotá D.C. durante el período 2006 a primer trimestre de 2015. La información para el período de estudio fue tomada de la base de datos del Sistema Único de Información de Servicios Públicos (SUI) de la Superintendencia de Servicios Públicos Domiciliarios. El análisis de la información cuantitativa, recabada para efectos de medir la calidad del servicio domiciliar revela que el servicio presenta fallas sostenidas desde 2009, año a partir del cual los reclamos sobre calidad, conexiones y trámites aumentaron considerablemente, teniendo su pico más alto en 2014. Los niveles de insatisfacción, por otra parte, son más altos en el Valle del Cauca y Atlántico que en Bogotá. Los resultados del estudio indican que las empresas deben ajustar la prestación del servicio y mejorar la velocidad de respuesta en el trámite de las peticiones, quejas y reclamos de los usuarios.

\section{Palabras clave}

Marketing; calidad; servicios.

\section{Resumo}

Esta pesquisa identifica os níveis de gás doméstico qualidade do serviço de pedidos e reclamações departamentos de Atlântico, Valle del Cauca e Bogotá DC durante o período de 2006 a primeiro trimestre de 2015. As informações para o período do estudo foi tirada da base de dados do Sistema de Informação Unified Utilities (SUI) da Superintendência de Serviços Públicos. A análise quantitativa das informações coletadas para fins de mensuração doméstico qualidade do serviço revela que o serviço tem realizado desde 2009, a partir do qual os créditos sobre falhas de qualidade, conexões e transações aumentou significativamente, com o seu pico mais alto em 2014. O níveis de insatisfação, por outro lado, são mais elevados em Valle del Cauca e no Atlântico do que em Bogotá. Os resultados do estudo indicam que as empresas devem ajustar a prestação de serviços e melhorar a velocidade de resposta no processamento de petições e reclamações dos usuários.

\section{Palavras chave}

Marketing; qualidade; serviços. 


\section{Introduction}

in Colombia, residential utilities such as water, electricity, sewage, garbage removal, gas, and phone service, among others, are constitutionally tied to the essential purposes of the State (C.P., art. 365.) In order to develop this, Law 142 of 1994 was issued stating that these services should be directly provided by the State or by a third party named private or mixed operators and their activity was regulated by the Superintendency of Public Utilities.

Residential utilities are understood as every activity displayed directly or indirectly by the State in order to satisfy the basic well-being and consumption needs in exchange for a fee.

The importance of residential utilities (RU) lies in:

Customers of utilities could be groups of individuals, the community or interest groups, elected members, legislators, or society in general. According to Hirmukhe (2013), these customers or interested parties can pay or not, receive the service or directly benefit from the service provided, as well as have different expectations regarding the quality of the service. This is what makes the task more difficult for the service providers. The complexity of the environment where the companies that provide the service operate requires that these understand that they are different from manufacturing companies and that their organization should be adjusted to the concrete reality of providing a public service. As a consequence, these companies are forced to adopt a "dominant public service" approach that reflexes more precisely the reality of contemporary public management based on a substantive dominant service theory that is more relevant for such public management than the previous manufacturing approach. Regarding this, Osborne, S.P., Radnor, Z, Nasi, G. (2013) contribute with an innovative idea regarding the management of utilities. This idea demands a narrower role between the strategic and operative levels of the companies that provide these services.

Likewise, Law 142 of 1994, in the 2nd article, besides guaranteeing the provision and competence of utilities, intervenes in order to ensure that these are provided in conditions of opportunity, priority attention, efficiency and access, as well as user participation.

Lee, S. Y., \& Kim, J. H (2014) studied loyalty and reuse in public service facilities. The results revealed that factors such as cleanliness, operation design, and easy access are essential factors for service qulity and satisfaction.

The purpose of this article is to identify the quality levels of residential gas service in the departments of Atlántico, Valle del Cauca, and in the city of Bogotá based on petitions, complaints, and claims generated in these territories. The information processed for the period studied (2006-2015) was taken from the database of the Unified Information System Utilities. 
The scope of this research is residential gas public service due to the fact that this sector establishes restrictions for its operation, coverage, and collection and because this sector is characterized for a market definition, where the carrier companies are the ones that own the distribution networks used for providing the service. According to the literature, this situation generates the development of quality evaluation models based on circulatory systems, that as stated by Guo, J., Liu, X (2014), include the service evaluation system, which includes the need for quality, the application system quality, the surveillance of quality in the system, and the quality of the evaluative system.

For authors like Carvalho, C., Brito, C. (2012), evaluating the perception of public service users is decisive when defining quality improvement. They recommend to pay special attention to the users' expectations and perceptions as well as to the role emotions play related to the service.

Holzer, M., Charbonneau, E., Kim, Y. (2009) are of the opinion that "quality" could be a subjective term where each organization suggests its own definitions and limits. They establish three aspects in order to improve quality: quality circles, total quality management, and citizen satisfaction. Having said that, quality improvement practices in the public sector have been promoted by the demands of the users, who search for more effective services, and by the generation of real quality models and standards.

Likewise, the object of study for this scope is the quality levels of the organizations that provide residential gas service provided that the literature suggests revising this in this kind of organizations: Achchuthan, S., Sivathaasan, N., Jayasundara, J.M.R.S. (2014) in order to help reduce the levels of dissatisfaction of the customers and to allow identifying beforehand existing risks, as Jordan states, S.R (2014).

Quality is a service dimension that has been omitted frequently. The results indicate that quality measurement represents opportunity cost and it is necessary to balance quantity and quality by having each one as a key point, as Picazo-Tadeo, A.J., Sáez-Fernández, F.J., González-Gómez, F. (2008) indicate.

The inclusion of quality level in the evaluation is justified, according to Destandau, F., Garcia, S. (2014), by the meaningful impact it has on economies of scale because quality in public services is tied to the social, economic, and demographic development of any country. Besides this, it is also a cause for concern for the service marketing environment, according to Pietrucha-Urbanik, K., Studzinski, A. (2012).

We selected the departments of Atlántico, Valle del Cauca, and the city of Bogotá for the evaluation of residential gas public service quality based on the high number of petitions, complaints, and claims (PCC) generated in these territories from 2006 to the first quarter of 2015 . 


\section{Sector context: residential gas in Colombia}

In Colombia, the structure of natural gas industry, as presented by the Energy and Gas Commission (CREG for its name in Spanish) in Figure 1, is determined by a market full of consumers or users that have a condition of regulated or not. In addition, there are agents, who are in charge of delivering the product to the user. Here, you can find the producers, transporters, distributors, and suppliers.

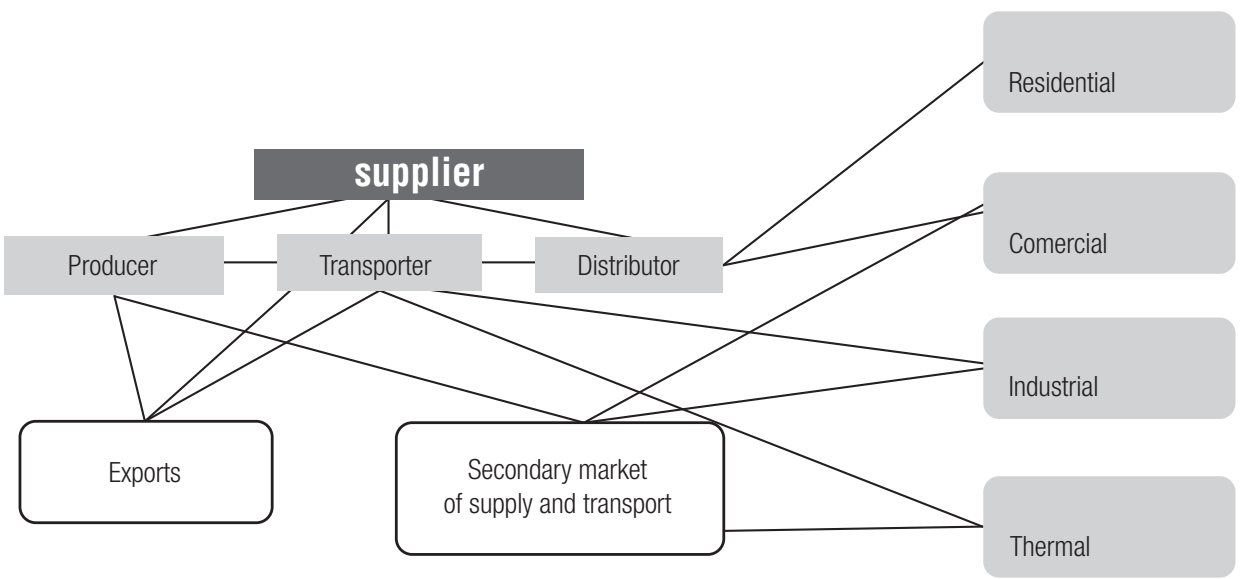

Figure 1. Structure of Natural Gas Industry in Colombia 2012

Source: Ministry of Mines/CREG. 2012

In order to develop this activity and its regulation, Law 142 of 1994 defined instruments for State intervention focused on: (I) Promotion and support to public service providers, (II) Resource management and procurement, (III) Regulation, (IV) Setting of efficiency goals, (V) Coverage, quality, and evaluation, (VI) Pricing regime, (VII) Information, training, and technical assistance systems, (VIII) Natural resource protection, (IX) Subsidy granting, (X) Investment incentive. (Law 142/1994; Cap. 1, Art 3 and ss).

By means of this, Law 142 of 1994 aimed to guarantee a better provision of the service, by enhancing its coverage to a greater number of users in a continuous, efficient, and permanent way, in such a way that the quality of life is improved.

\subsection{Quality of Service}

When talking about public services, quality of service and customer satisfaction are concepts whose reach and meaning need to be specified. For this reason, service should be understood as the result of several activities that are distributed by a supplier in order to benefit and satisfy a customer. All this, by understanding that quality implies the continuity in the provision of the service, among others. This aspect is contractile and regulated at the same time. For this reason, a public service is not necessarily provided by the State in order to guarantee its provision and quality. The participation of the 
private sector, as could be observed, does not necessarily lead to quality deterioration, as Fumagalli, E., Garrone, P., Grilli, L, (2007) indicate.

Because providing a service is considered a basic service, the State is responsible. Service interruptions generate discomfort among users, which, at the same time, brings as a consequence serious health problems as well as esthetic restlessness and environmental impact. Therefore, it is essential to determine the quality of residential public service, as authors Alejandrina, S., Emily, M., Enemarsy, G. (2011) explain in their study.

In addition, the concept of quality of service, as pointed out by some theorists and studies (Parasuraman, A., Zeithaml, V. A., \& Berry, L. L. (1985) is multidimensional and includes aspects such as reliability, security, empathy, and response capacity, among others.

This leads to the definition of quality of service in terms of "the degree of discrepancy between consumer's service perception and expectations”, according to Himukhe, (2013).

On the other hand, the literature indicates that the design of quality rules for public services allows incentive regulation in order to achieve cost saving without affecting cost expenditures and quality of service: (Ter-Martirosyan, A., Kwoka, J., 2010). Also, this topic is immersed in correlative theories such as public service quality management, interaction quality, and satisfaction degree to deal with the key points of quality of public service in practice, according to authors like Yang, K., Hu, J., Wang, B. (2010).

In this order of ideas, the State should tend to protect the interests of the users by promoting quality in the service provided and by certifying a fair balance of the income, guaranteeing the principles of essentiality, equity, indispensability, feasibility, and costeffectiveness, as Duarte A.A.L.S., Rodrigues, G.M.C., Ramos, R.A.R. (2009) indicate.

Another contribution of the literature that sets service satisfaction as a variable point, is the work of Agus, Barker, and Kandampully (2007). They indicate that there are key relations among the dimensions of the service, its performance, and its quality within the public service in Malesia. This and the previous models mentioned use questionnaires with simple random sampling for their researches.

In addition, internal marketing actions can have a direct, meaningful, and positive effect in the behaviour of public service users. The model proposed and the results of the research can help the organization that provides the service to offer better quality to its internal and external customers. The results of this research are very valuable because it has been possible to provide the organization with tangible results. As shown by SeyedJavadin, S., Rayej, H., Yazdani, H., Estiri, M., Aghamiri, S.A. (2012).

Interaction quality has influence on the predisposition of citizens regarding their evaluation of high or low services based on the type of service consumption: by choice or by coercion, as stated by Brown, T. (2007). For this reason, it is necessary to establish improved efforts in the processes aimed for the provision of a service. According to Holt (2005), quality identifies several measures to promote the performance of the sector in an efficient way. 
Customer segments are identified as a perceived quality and profile function and are established for each group of users, which make it more efficient, being quality of service a useful tool for each public service segment, as Sánchez-Pérez, M., Sánchez-Fernández, R., Marín-Carrillo, G.M., Gázquez-Abad, J.C. (2007) claim.

Different approaches have been adopted by different public service leaders in order to establish a strategic addressing, according to Milner, E., (2012). The findings suggest that the critical attributes of public service quality for customer satisfaction differ according to the types of customers within the public sector, as stated by Rhee Seung-Kyu, S.-K., Rha, J.-Y. (2009).

The results also support the positive effects of the convenience and the satisfaction perceived regarding quality of service, as suggested by Lee, S. Y., \& Kim, J. H (2014). This may lead to the development of an evaluation model for quality of public service based on circulatory systems, including: the objective evaluation system, the quality needs, the application system quality, the surveillance of the system quality, and the system quality, according to Guo, J., Liu, X, (2014).

Chodzaza, G. E., \& Gombachika, H. S. H (2013) suggest that industrial customers perceive quality of service as deficient regardless of their demographic characteristics. This means that having a satisfied customer implies continuous improvement. The provision of a service is directly related to the dimensions of reliability, tangibility, empathy, guarantee, security, and stability, and when there are service interruptions when providing a public service, the customers are not satisfied, according to Satapathy, S., (2014).

The concept of quality is subjectively tied to the appreciation of each specific customer. A favorable concept depends on the capacity the company that provides a public residential service has to know, understand, and solve the needs of a customer in an efficient way and with an excellent commitment for the provision of the service.

The importance of interacting the service to the public satisfaction as well as understanding the quality improvement of a public service are for Yang, K. et al (2010) motivational and behavioral attitudes with respect to the evaluation of the service and, for Sharma, H. (2010), implies a series of characteristics that the user evaluates when establishing a complaint or claim. A flaw noticed in quality analysis is that companies tend to focus on production expenses without taking into account quality key dimensions. The introduction of quality variables affects performance comparisons in public services. For this reason, according to Lin, C. (2005), quality should be incorporated in comparative evaluation studies.

When measuring quality of service, it is important to take into account customer satisfaction, tied to the quality attributes that the customer considers approved with respect to the companies that provide a public residential service, being also relevant the idea of fulfilling current regulations when providing the service. According to this, this measurement can be carried out under the criteria exposed in Table 1. 


\section{Table I.}

Service quality dimensions 1985

\begin{tabular}{|c|c|c|c|c|}
\hline Empathy & Reliability & Security & $\begin{array}{l}\text { Response } \\
\text { Capacity }\end{array}$ & Tangibility \\
\hline $\begin{array}{l}\text { To know and un- } \\
\text { derstand the cus- } \\
\text { tomer by providing } \\
\text { a customized ser- } \\
\text { vice. }\end{array}$ & $\begin{array}{l}\text { Ability to pro- } \\
\text { vide the ser- } \\
\text { vices proposed } \\
\text { in a reliable } \\
\text { way. }\end{array}$ & $\begin{array}{l}\text { To increase the } \\
\text { credibility and } \\
\text { the trust that } \\
\text { employees in- } \\
\text { spire. }\end{array}$ & $\begin{array}{l}\text { To determine } \\
\text { the answer } \\
\text { effectiveness } \\
\text { in a specific } \\
\text { situation. }\end{array}$ & $\begin{array}{l}\text { Aspects of } \\
\text { physical facil- } \\
\text { ities, equip- } \\
\text { ment, and } \\
\text { personnel. }\end{array}$ \\
\hline
\end{tabular}

Source: Parasuraman, Zeithami, and Berry (1985)

Measurement is the focal point for public service quality management and it is derived from the establishment of a system that measures its performance by considering four dimensions: Operation performance, degree of customer satisfaction, financial and human resources performance, Wang, J (2011) states.

Øvretveit, J. (2009) suggests that quality of service should be focused on the value perceived by the customer and with this, on orienting and generating a culture within the employees in order for them to make an effort in improving their processes, taking into account surveillance measurements over their performance.

Quality levels of Residential Public Utilities include activities that go from receiving a customer, the reception, record, procedure, and solution of the requirement presented and that is related to petitions, complaints, claims, and resources, the generation of a solution or answer to the evaluation of an answer.

Setting needs is perceived on different channels such as: Customized service in the public attention area of a company and by phone. In this sense, classification systems before global changes regarding the provision of a service in order to minimize complains, claims, or petitions should establish special characteristics about how to reach the customer by means of efficiency and the constant improvement of the product Hood, C., (2007).

\section{Methodological strategy}

This research is addressed from a pragmatic paradigm. Its design is descriptive, not experimental. In order to measure the factors that affect the quality of residential gas service, this study uses the information that is available regarding petitions, claims, and complaints at the Superintendency of Public Utilities.

Due to the research problem to be studied, we carried out a descriptive analysis of the information that is both univariate and bivariate in order to characterize, classify, and relate the different variables. The information is taken from a database of the Unified Information System Utilities (SUI from now on) for the years between 2006 and the first quarter of 2015. The system includes variables related to complaints, appeals filed, and 
petitions made in the departments of Valle del Cauca, Atlántico, and the city of Bogotá that exceed more that a million of inhabitants.

On the other hand, we suggest a framework structured through longitudinal data that identify key service processes from the perspective of the customer by establishing improved efforts in the processes for the provision of a service.

Likewise, the study carried out by the Superintendency of Public Utilities (SSPD for its name in Spanish) examines a series of quality variables and the way they affect performance through the provision of a service by showing different specifications of the service provided in the different cities considered.

\section{Results}

We used the information regarding the petitions, claims, and complaints published by the Superintendency of Public Utilities, focusing on the companies that provide residential gas service in different regions: Valle del Cauca, Atlántico, and Bogotá from 2006 (according to the PCC) to the first quarter of 2015.

The departments of Atlántico, Valle del Cauca, and the city of Bogotá are the places where there are more PCC in comparison with the rest of departments of Colombia according to the SUI of the Residential Gas Service.

Figure 2 shows the type of procedure per company that provides the service and there is a noticeable difference between the number of petitions in Valle and the Caribbean vs Bogotá, that represents only $14.41 \%$ of the total, whereas Valle and the Caribbean register $45.45 \%$ and $40.14 \%$ respectively.

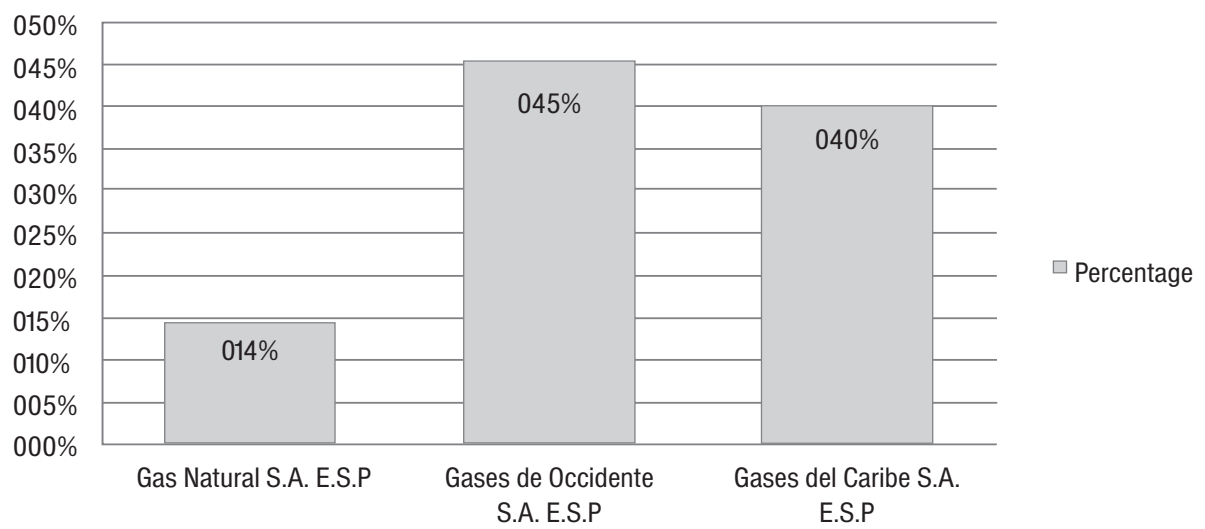

Figure 2. Type of procedure per company that provides the service

By using the statistical program, we analyzed the information gathered from the SUI database for the period studied. A temporary series that is extensive, reliable, and 
updated enough identifies the performance of sensible variables in order to determine the customer satisfaction levels regarding residential utilities in the country. For this study, the measurement of customer satisfaction levels regarding residential gas service indicates that the greater types of complaints made at the Superintendency of Public Utilities are because of procedures with $33.82 \%$.

The results shown in Figure 3 display that the complaints for procedures have an important percentage in the three regions studied, as does quality of service. Complaints for connections are in third place with collections, representing to a lesser degree a factor that generates claims and complaints. This tendency is individually represented in Figure 4.

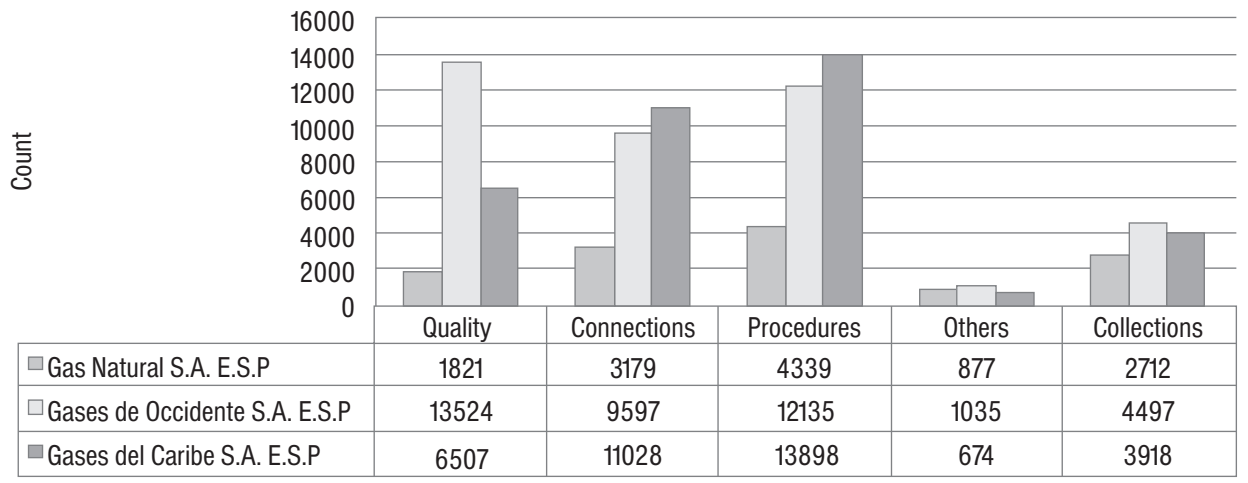

Figure 3. Type of complaint per company that provides the service

Source: Superintendency of Public Utilities (2015)

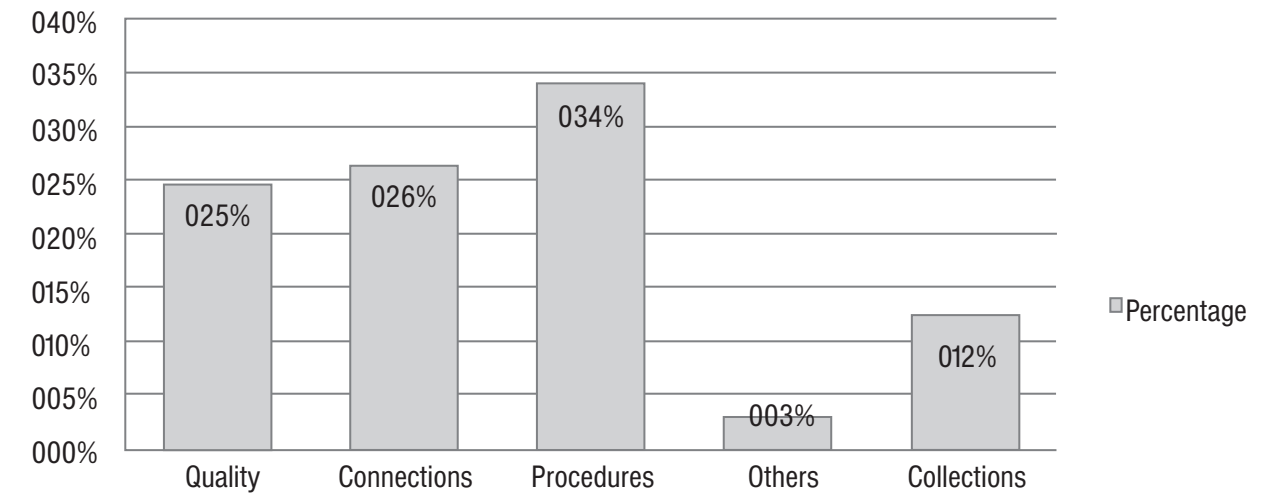

Figure 4. Type of complaint

Source: Superintendency of Public Utilities (2015)

Petitions or claims occupy more tan $90 \%$ of the procedures carried out by users within the three regions. The results of reconsideration and appeal are $4.6 \%$ and $4.17 / \%$ respectively, as shown in Figure 5. 
Figure 6 presents the response given by the companies that provide the service with respect to the complaints from the residential gas service users. $24 \%$ of those complaints are accepted, $23 \%$ have not been answered yet, and a significant $28 \%$ is not accepted, while almost $8 \%$ is partially accepted.

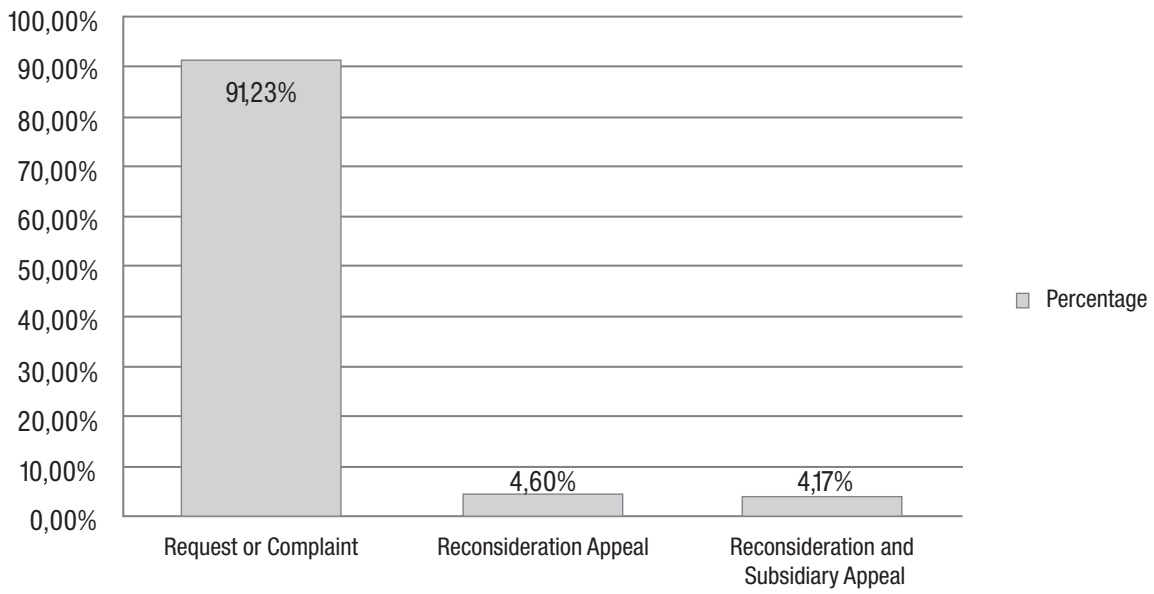

Figure 5. Type of procedure presented to the per company that provides the service

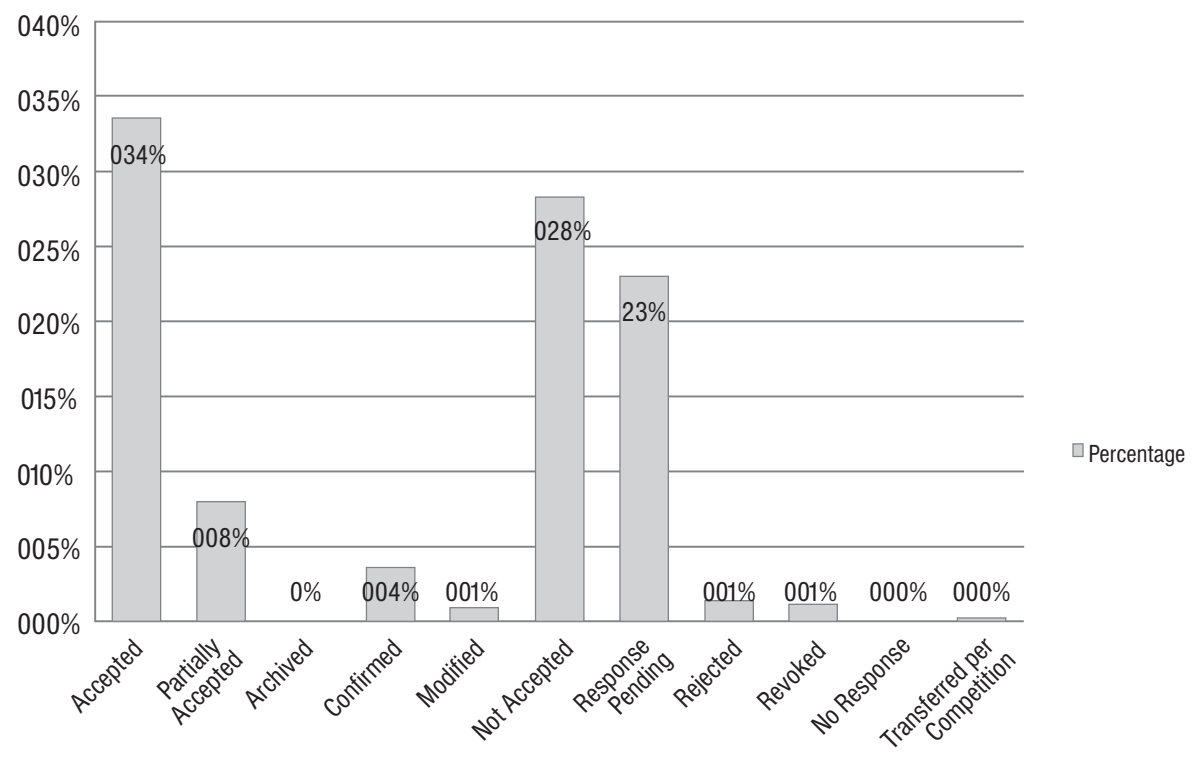

Figure 6. Type of response given by the company that provides the service 
Figure 7 presents the behavior of PCC per month between 2006 and 2015. There are two very low values in March and June, being January and April the months with more frequencies. However, Figure 8 shows that the complaints are very similar in number and type every month.

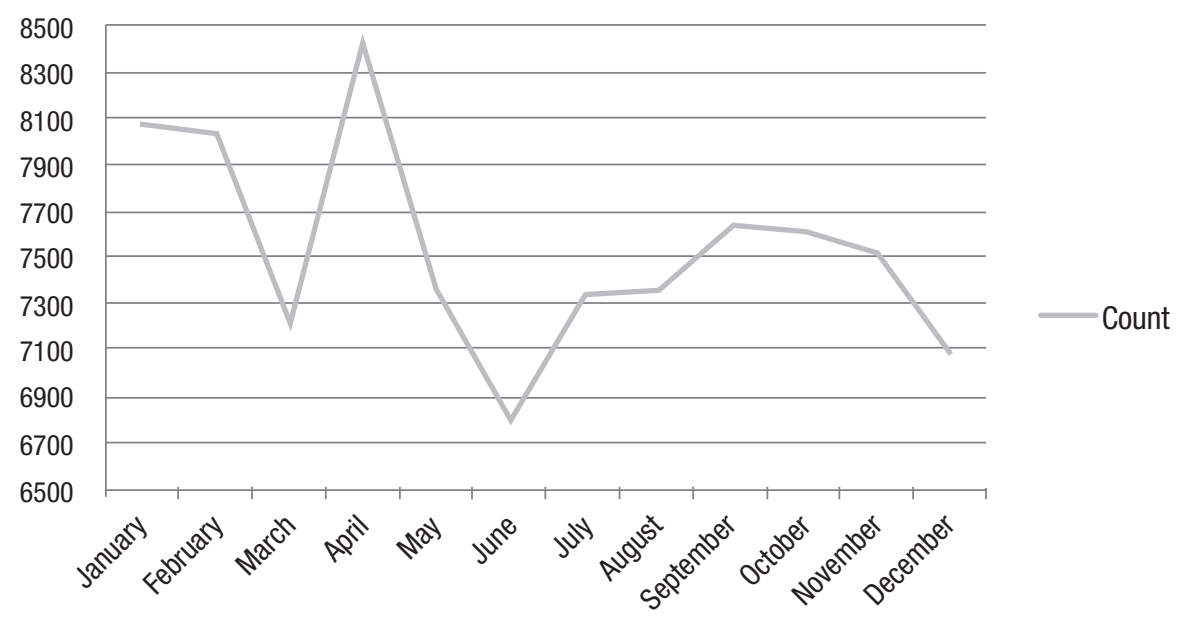

Figure 7. Monthly PCC behavior

Source: Superintendency of Public Utilities (2015)

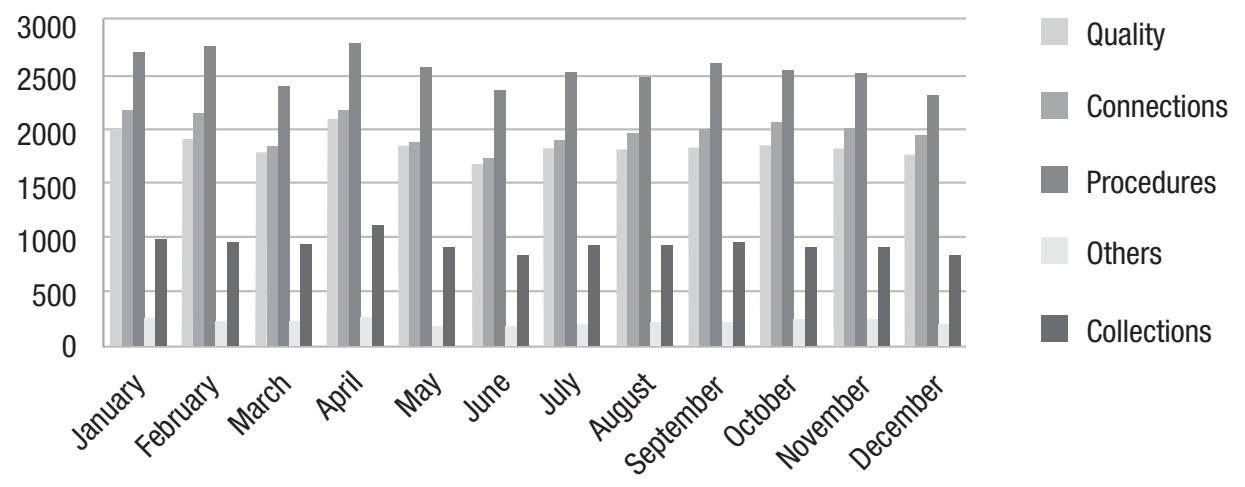

Figure 8. Monthly PCC behavior per type of complaint

Source: Superintendency of Public Utilities (2015)

The behavior of petitions, complaints, and claims (PCC) between 2006 and 2014 increases from 2009. During this year there was a minor decrease, which can be observed in Figure 9. 


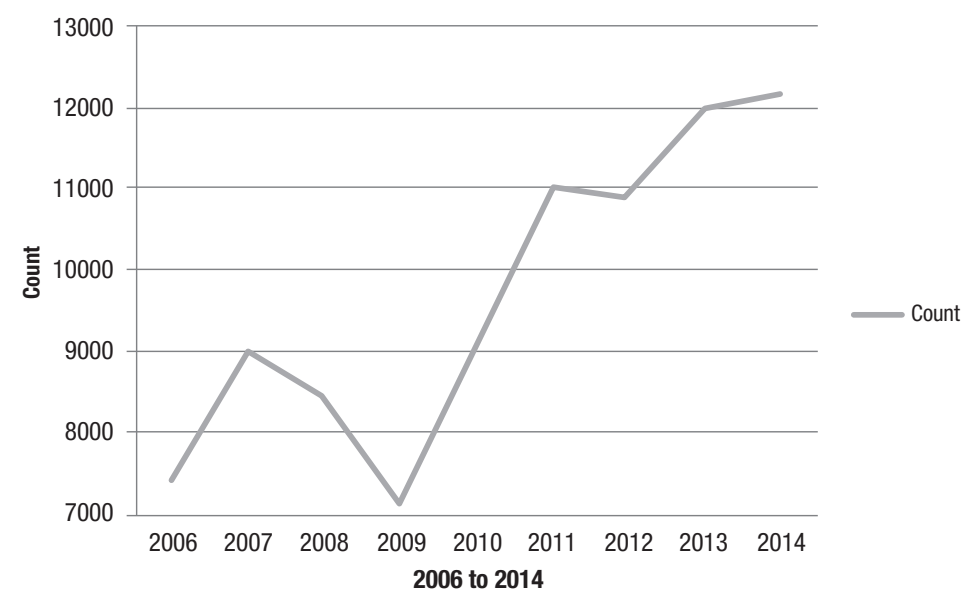

Figure 9. Annual PCC behavior between 2006 and 2014

\section{Discussion and conclusions}

The orientation of the article is based on the evaluation of the residential gas service provided in the departments of Atlántico, Valle del Cauca, and the city of Bogotá between 2006 and the first quarter of 2015. The identification and evaluation of the factors that determine the quality levels of the residential gas service were carried out based on the information found in the SUI, available at the Superintendency of Public Utilities.

In order to measure the levels of satisfaction regarding residential gas quality of service, we gathered the information related to petitions, claims, and complaints registered for the period studied.

The information was analyzed per company that provided the service, types of procedures, and level of response with respect to petitions, claims, and complaints made by the people who use the service.

It can be observed that the levels of dissatisfaction for the period studied increased, especially in the departments of Valle del Cauca and Atlántico, reaching their highest peak in 2014. This is shown in the highest percentages of PCC and procedures, $45.45 \%$ and $40.14 \%$, respectively; while the lowest levels of petitions, claims, or complaints made by the users of this service (Superintendency of Public Utilities) are shown in the city of Bogotá.

The follow-up made to these numbers for the selected variables allows establishing that the current status of the gas service presents product failures that are reflected in the increase of the users' levels of dissatisfaction. The high number of PCC is clear evidence of this. In this sense, a high number of petitions, complaints, and claims is a good indication of the perceptions customers have towards the quality of the service and the difference between the quality received and their expectations. 
This situation of non-conformity demands that the companies that provide the service offer effective solutions. The results obtained here indicate to these companies the need to structure procedures and systems that allow improving their response time with respect to the petitions, complaints, and claims of the users. This is without a doubt a critical point because the high level of interruptions registered does not have timely and effective response levels, which proves that during the period studied, there were more claims and complaints. The difference between the levels of dissatisfaction observed between the departments of Valle del Cauca and Atlántico with respect to the city of Bogotá are meaningful. They seem to indicate at the same time differences within operation and management models by the companies that provide residential gas service.

The findings of the study of the Superintendency of Public Utilities suggest that the critical quality attributes of public service for users' satisfaction change according to the types of customers. The most recent international literature about this topic also indicates that quality criteria and the evaluation in order to improve quality management are also different.

\section{Conflict of interests}

The authors declare that they have no conflict of interest.

\section{References}

1. Achchuthan, S., Sivathaasan, N., Jayasundara, J.M.R.S. (2014) Service quality dimensions of electricity services: Evidence from electricity board in Sri Lanka. Asian Social Science. 10 (17) $194-203$

2. Alejandrina, S., Emily, M., Enemarsy, G.(2011). Public service quality for urban sanitation. Case: The maracaibo municipality [Calidad del servicio público de aseo urbano. Caso: Municipio maracaibo]. Revista Venezolana de Gerencia V. 16 (56) 622$639 \mathrm{http}: / /$ www.scopus.com/inward/record.url?eid=2-s2.0-84856322601\&partnerID $=40 \& \mathrm{md} 5=\mathrm{ccd} 78317 \mathrm{a} 26 \mathrm{dc} 854768433 \mathrm{f} 19 \mathrm{fbba} 020$

3. Agus, A., Barker, S., Kandampully, J. (2007) An exploratory study of service quality in the Malaysian public service sector. International Journal of Quality and Reliability Management. V 24 (2). 177 - 190.

4. Brown, T. (2007). Coercion versus choice: Citizen evaluations of public service quality across methods of consumption. Vol. 67. 559 - 572.

5. Carvalho, C., Brito, C. (2012) Assessing Users' Perceptions on how to Improve Public Services Quality. Public Management Review. 14 (4). 451-472. DOI: 10.1080/14719037.2011.649976

6. Constitución Política de Colombia (1991) art. 365

7. Chodzaza, G. E., \& Gombachika, H. S. H (2013). Service quality, customer satisfaction and loyalty among industrial customers of a public electricity utility in Malawi. International Journal of Energy Sector Management, 7 (2), 269-282. doi:10.1108/ IJESM-02-2013-0003

8. Destandau, F., Garcia, S. (2014). Service quality, scale economies and ownership: An econometric analysis of water supply costs. Journal of Regulatory Economics. DOI: 10.1007/s11149-014-9250-2 
9. Duarte A.A.L.S., Rodrigues, G.M.C., Ramos, R.A.R. (2009). A global service quality index to evaluate the performance and sustainability in water supply utilities, WSEAS Transactions on Environment and Development. p 759 - 769

10. Fumagalli, E., Garrone, P., Grilli, L. (2007). Service quality in the electricity industry: The role of privatization and managerial behavior. p $6212-6224$

11. Guo J., Liu, X. A (2014) process-control based public service quality evaluation model, ICLEM 2014: System Planning, Supply Chain Management, and Safety - Proceedings of the 2014 International Conference of Logistics Engineering and Management. (pp 671-678)

12. Hirmukhe, J (2013). Measuring the customer's perception of service quality using SERVQUAL in public services. International Journal of Services, Technology and Management, 19 (4-6), 267-277. http://doi.org/10.1504/IJSTM.2013.055622

13. Holzer, M., Charbonneau, E., Kim, Y. (2009). Mapping the terrain of public service quality improvement: Twenty-five years of trends and practices in the United States. International Review of Administrative Sciences. 75 (3). 403-418. DOI: 10.1177/0020852309341330

14. Hood, C. (2007) Public service management by numbers: Why does it vary? Where has it come from? What are the gaps and the puzzles?. Public Money and Management. DOI: 10.1111/j.1467-9302.2007.00564.x

15. Holt, L. (2005). Utility service quality - Telecommunications, electricity, water, Utilities Policy. 13 (3). 189-200. DOI: 10.1016/j.jup.2004.08.003

16. Jordan, S.R. (2014). Public Service Quality Improvements: A Case for Exemption from IRB Review of Public Administration Research 21 (2), 85-108. DOI: 10.1080/08989621.2013.804347

17. Lee, S. Y., \& Kim, J. H (2014). Effects of servicescape on perceived service quality, satisfaction and behavioral outcomes in public service facilities. Journal of Asian Architecture and Building Engineering, 13 (1), 125-131. http://doi.org/10.3130/ jaabe.13.125

18. Ley 142 Diario Oficial 41.433 del 11 de julio de 1994. Por la cual se establece el régimen de los servicios públicos domiciliarios y se dictan otras disposiciones. Bogotá, 1994. No. 41.433. Cap. I, II Art 1, 2, 3 y ss

19. Lin, C. (2005).Service quality and prospects for benchmarking: Evidence from the Peru water sector. Utilities Policy. 13 (3). 230-239. DOI: 10.1016/j.jup.2005.04.002

20. Milner, E., (2012) Lessons in leadership: Meeting the challenges of public services management. Lessons in Leadership: Meeting the Challenges of Public Services Management (1). 177. DOI: 10.4324/9780203617793

21. Ministerio de Minas y Energía. Comisión de Regulación de Energía y Gas, CREG. (1996). "Resolución 057”. Bogotá

22. Osborne, S.P., Radnor, Z, Nasi, G. (2013) A New Theory for Public Service Management? Toward a (Public) Service-Dominant Approach 43 (2) 135-158. Doi: 10.1177/0275074012466935.

23. Øvretveit, J.(2009). Public Service Quality Improvement. The Oxford Handbook of Public Management. Link. http://www.scopus.com/inward/record.url?eid=2-s2.084923415139\&partnerID=40\&md5=6f87846d4bda8d610ac98ee9d0b21468 
24. Parasuraman, A., Zeithaml, V. A., \& Berry, L. L. (1985). A conceptual model of service quality and its implications for future research. the Journal of Marketing, 41-50.

25. Picazo-Tadeo, A.J., Sáez-Fernández, F.J., González-Gómez, F. (2008). Does service quality matter in measuring the performance of water utilities? Utilities Policy. Vol. (16) P. 30-38.

26. Pietrucha-Urbanik, K., Studzinski, A. (2012) Standards of water services quality levels with regard to the reliability of water supply to the recipients. Journal of Konbin. 24 (1), 71-78. DOI: 10.2478/jok-2013-0054

27. Rhee Seung-Kyu, S. -K, Rha, J. - Y. (2009) Public service quality and customer satisfaction: Exploring the attributes of service quality in the public sector 2009. Service Industrial Journal. doi: 10.1080/02642060902793441.

28. Sánchez-Pérez, M., Sánchez-Fernández, R., Marín-Carrillo, G.M., Gázquez-Abad, J.C. (2007) Service quality in public services as a segmentation variable. Service Industrial Journal.Vol.24 P. 355 - 369 Doi: 10.1080/02642060701346771.

29. Satapathy, S. (2014) An analysis for service quality enhancement in electricity utility sector of india by SEM. Benchmarking. 21 (6). 964-986. DOI: 10.1108/BIJ-10-20120071.

30. Sharma, H. (2010). Modeling customer perceived service quality for electricity supply in South Haryana. 3 (1). 73-91. Link: http://www.scopus.com/inward/record. url?eid=2-s2.0-79952678149\&partnerID=40\&md5=948dc85dac9a580fed 23 faa 48800 ea82.

31. SeyedJavadin, S., Rayej, H., Yazdani, H., Estiri, M., Aghamiri, S.A. (2012). How organizational citizenship behavior mediates between internal marketing and service quality: The case of Iranian GAS company. International Journal of Quality and Reliability Management. Vol. 25 (5) 512- 530 link: http://www.scopus.com/inward/ record.url?eid=2-s2.0-84860851609\&partnerID=40\&md5=562db99844ccc0ef78da19f $1 \mathrm{e} 6 \mathrm{a} 9 \mathrm{e} 354$.

32. Ter-Martirosyan, A., Kwoka, J. (2010) Incentive regulation, service quality, and standards in U.S. electricity distribution. Journal of Regulatory Economics 38 (3), 258-273. DOI: 10.1007/s11149-010-9126-z.

33. Yang, K., Hu, J., Wang, B. (2010) RETRACTED ARTICLE: Studies on the factors of interaction quality in public service quality management. Proceedings of the International Conference on E-Business and E-Government, ICEE 2010. 4554-4557. DOI: 10.1109/ICEE.2010.1143.

34. Wang, J. (2011). Establishing the index system for performance measurement of local government's public service quality management. 